\title{
Advances in Photoreactive Tissue Adhesives Derived from Natural Polymers
}

\author{
Amal Narayanan, Ying Xu, Ali Dhinojwala and Abraham Joy *(D) \\ Department of Polymer Science, The University of Akron, Akron, OH 44325, USA; an75@zips.uakron.edu (A.N.); \\ yingxu1217@163.com (Y.X.); ali4@uakron.edu (A.D.) \\ * Correspondence: abraham@uakron.edu
}

Received: 28 March 2020; Accepted: 6 May 2020; Published: 9 May 2020

\begin{abstract}
To stop blood loss and accelerate wound healing, conventional wound closure techniques such as sutures and staples are currently used in the clinic. These tissue-piercing wound closure techniques have several disadvantages such as the potential for causing inflammation, infections, and scar formation. Surgical sealants and tissue adhesives can address some of the disadvantages of current sutures and staples. An ideal tissue adhesive will demonstrate strong interfacial adhesion and cohesive strength to wet tissue surfaces. Most reported studies rely on the liquid-to-solid transition of organic molecules by taking advantage of polymerization and crosslinking reactions for improving the cohesive strength of the adhesives. Crosslinking reactions triggered using light are commonly used for increasing tissue adhesive strength since the reactions can be controlled spatially and temporally, providing the on-demand curing of the adhesives with minimum misplacements. In this review, we describe the recent advances in the field of naturally derived tissue adhesives and sealants in which the adhesive and cohesive strengths are modulated using photochemical reactions.
\end{abstract}

Keywords: photocurable adhesive; polysaccharide tissue adhesive; protein tissue adhesive; tissue engineering

\section{Introduction}

More than 50 million surgical procedures are performed in the United States every year [1]. Surgical tools such as sutures and staples are frequently used in the procedures to prevent the loss of air, body fluids, and blood [2,3]. The tissue-penetrating nature of these techniques may lead to scar formation, cystic fibrosis, infections, and postoperative complications [4,5]. An alternative and emerging method for overcoming the disadvantages caused by invasive methods is the usage of materials that are either hemostats, sealant, or adhesives [6]. A diverse library of naturally derived, semi-synthetic, and synthetic materials is available with the potential to substitute for sutures in some applications. For example, fibrin sealants marketed as Tisseel ${ }^{\mathrm{TM}}$, Evicel $^{\circledR}$, Vitagel $^{\mathrm{TM}}$, Tachosil ${ }^{\circledR}$, and Artiss actively promote the blood coagulation cascade and show superior hemostatic and sealing capability [6]. However, the interfacial adhesion strength of fibrin sealants to tissues is weak, and there remains a need for adhesives and sealants with strong adhesion to injured tissue surfaces in wet conditions. Adhesives based on the reaction of cyanoacrylate with nucleophiles and of albumin with dialdehydes were developed to create strong tissue adhesives $[7,8]$. The products developed using such chemistries show improved adhesion strength compared to fibrin-based sealants [6]. However, due to the fast-reactive nature, the adhesive may cause an embolism, tissue necrosis, and misplacements [9-11].

An ideal tissue adhesive must flow and adhere rapidly to the surface, conform to tissue shapes and resist deformation from mechanical stress, cause no toxicity, and be bioabsorbable [12]. For a tissue adhesive to be safe and effective, spatial and temporal control of the adhesive and cohesive strength is crucial [13]. Materials that show physical and chemical changes when exposed to light provide 
an opportunity to modulate material properties spatially and temporally [14,15]. A diverse range of photochemical reactions such as photoinitiated free radical polymerization [16-18], electron transfer reactions [19,20], and [2 + 2]-photocyloadditions [21-23] (Figure 1 and Table 1) have been reported in the literature to provide materials with tissue adhesive capabilities. Most of the photochemically activated tissue adhesives involve the modification of naturally occurring polymers such as polysaccharides and proteins with photoactive chemical groups. Naturally occurring polymers provide wide varieties of polymer backbones, biocompatibility, and bioabsorption [24,25]. Several excellent reviews are available that summarize the progress in a broad range of tissue adhesives [6,13,26-31]. In this review, we focus on summarizing the design and development of tissue adhesives derived from naturally occurring polymers whose adhesive or cohesive strengths are photochemically initiated and modulated.

\section{Mechanisms of Photoinitiated Free Radical Polymerization}

\section{Norrish Type I Photoinitiation}

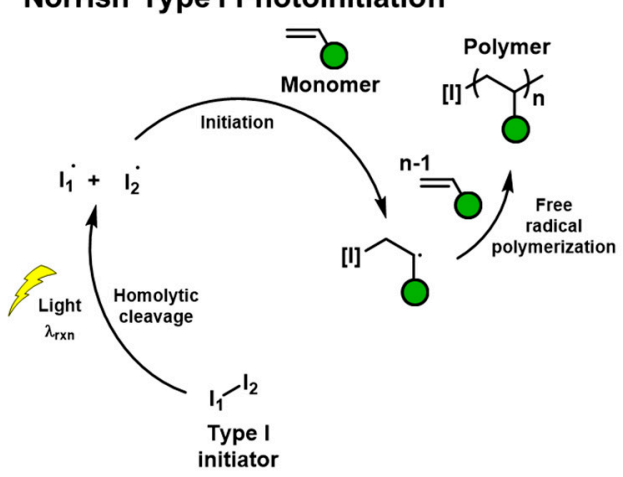

Norrish Type II Photoinitiation

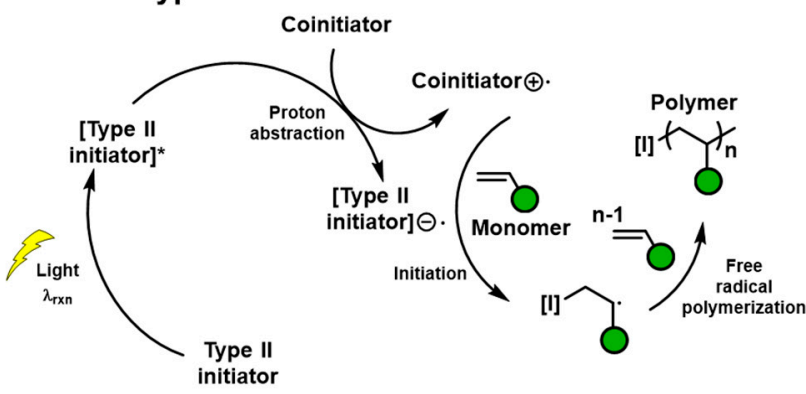

Mechanism of [2+2] Photocyloaddition

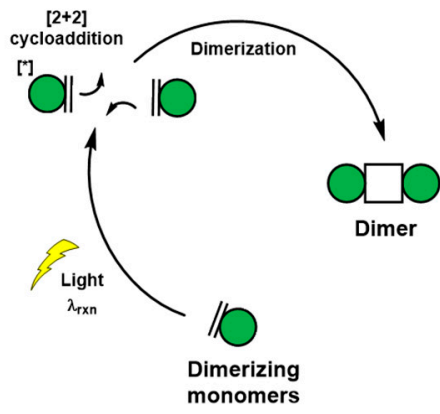

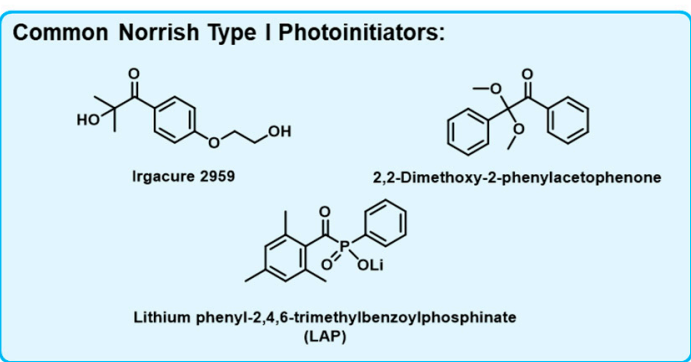

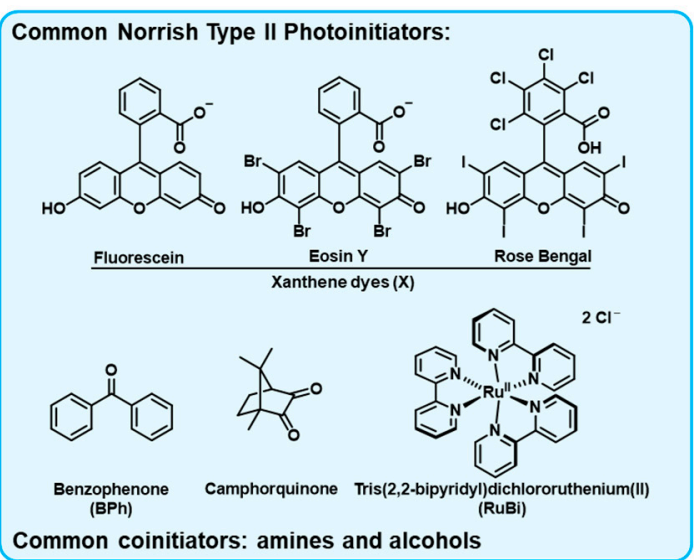

Figure 1. Mechanisms of the photoreactions popularly used in naturally derived tissue adhesive materials. The commonly used initiators and photoreactive molecules are listed.

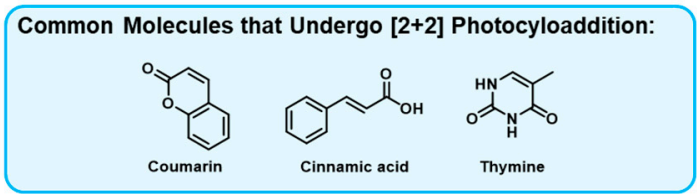


Table 1. Summary of the photoreactive tissue adhesives derived from natural polymers.

\begin{tabular}{|c|c|c|c|c|c|}
\hline $\begin{array}{l}\text { Natural } \\
\text { Polymer }\end{array}$ & $\begin{array}{c}\text { Subclass of Natural } \\
\text { Polymer }\end{array}$ & [a] Gelation System & Photoinitiator System & $\begin{array}{l}\text { Mechanism of } \\
\text { Crosslinking }\end{array}$ & Ref. \\
\hline \multirow{8}{*}{ [a] Proteins } & \multirow{5}{*}{$\begin{array}{l}\text { Gelatin (Gel) } \\
\text { Section 2.1.1 }\end{array}$} & $\begin{array}{l}\text { Benzophenone (BPh) and } \\
\text { xanthene }(\mathrm{X}) \text { dyes } \\
\text { conjugated Gel mixed with } \\
\text { PEGDA }\end{array}$ & $\mathrm{BPh}$ and $\mathrm{X}$ pendant groups & $\begin{array}{l}\text { Free radical } \\
\text { polymerization (FRP) } \\
\text { using Norrish type II } \\
\text { photoinitiator }\end{array}$ & 17,37 \\
\hline & & $\begin{array}{l}\text { Styrene pendant Gel mixed } \\
\text { with PEGDA and } \\
\text { carboxylated } \\
\text { camphorquinone }(C Q)\end{array}$ & CQ & $\begin{array}{l}\text { FRP using Norrish } \\
\text { type II photoinitiator }\end{array}$ & $12,39-41$ \\
\hline & & $\begin{array}{l}\text { Phenol pedant Gel mixed } \\
\left.\text { with }[\mathrm{Ru}(\mathrm{II}) \mathrm{bpy}]_{3}\right]^{2+}(\mathrm{RuBi}) \\
\text { and sodium persulfate (SPS) }\end{array}$ & RuBi and SPS & $\begin{array}{l}\text { Electron transfer }(\mathrm{ET}) \\
\text { reaction using } \\
\text { Norrish type II } \\
\text { photoinitiator }\end{array}$ & $42-44$ \\
\hline & & \multirow{2}{*}{$\begin{array}{l}\text { Methacrylamide pendant } \\
\text { Gel (GelMA) mixed different } \\
\text { photoinitiators }\end{array}$} & Irgacure 2959 & $\begin{array}{l}\text { FRP using Norrish } \\
\text { type I photoinitiator }\end{array}$ & 45 \\
\hline & & & Eosin-Y, TEA, $N$-vinylcaprolactam & $\begin{array}{l}\text { FRP using Norrish } \\
\text { type II photoinitiator }\end{array}$ & 46 \\
\hline & $\begin{array}{l}\text { Fibrinogen } \\
\text { Section 2.1.2 }\end{array}$ & $\begin{array}{l}\text { Fibrinogen mixed with RuBi } \\
\text { and SPS }\end{array}$ & RuBi and SPS & $\begin{array}{l}\text { ET reaction using } \\
\text { Norrish type II } \\
\text { photoinitiator }\end{array}$ & 20,49 \\
\hline & \multirow[b]{2}{*}{$\begin{array}{l}\text { Recombinant proteins } \\
\text { Section 2.1.3 }\end{array}$} & $\begin{array}{l}\text { Recombinant mussel protein } \\
\text { adhesive mixed with RuBi } \\
\text { and SPS }\end{array}$ & RuBi and SPS & $\begin{array}{l}\text { ET reaction using } \\
\text { Norrish type II } \\
\text { photoinitiator }\end{array}$ & 56 \\
\hline & & $\begin{array}{l}\text { Recombinant tropoelastin } \\
\text { with pendant } \\
\text { methacrylamide (MeTro) } \\
\text { and MeTro mixed with } \\
\text { GelMA }\end{array}$ & Irgacure 2959 & $\begin{array}{l}\text { FRP using Norrish } \\
\text { type I photoinitiator }\end{array}$ & 58,59 \\
\hline \multirow{9}{*}{$\begin{array}{c}{[\mathrm{a}]} \\
\text { Polysaccharides }\end{array}$} & $\begin{array}{l}\text { Alginate (Alg) } \\
\text { Section 2.2.1 }\end{array}$ & $\begin{array}{l}\text { Methacrylate pendant native } \\
\text { and oxidized Alg with } \\
\text { Norrish type II } \\
\text { photoinitiator }\end{array}$ & Eosin-Y, TEA, and 1-vinyl-pyrrilidinone & $\begin{array}{l}\text { FRP using Norrish } \\
\text { type II photoinitiator }\end{array}$ & 63,64 \\
\hline & \multirow{4}{*}{$\begin{array}{l}\text { Chitosan }(\mathrm{CH}) \\
\text { Section } 2.2 .2\end{array}$} & $\begin{array}{l}\mathrm{CH} \text { with pendant benzyl } \\
\text { azide and lactobionic acid }\end{array}$ & Benzyl azide pedant groups & $\begin{array}{l}\text { Nucleophilic attack } \\
\text { of nitrene groups to } \\
\text { various functional } \\
\text { groups }\end{array}$ & $67-70$ \\
\hline & & $\begin{array}{l}\text { CH modified with thiol } \\
\text { pendant groups mixed with } \\
\text { PEG-dimethacrylate and } \\
\text { Irgacure } 2959\end{array}$ & Irgacure 2959 & $\begin{array}{l}\text { Thiol-ene reaction } \\
\text { initiated by Norrish } \\
\text { type I photoinitiator }\end{array}$ & 71 \\
\hline & & $\begin{array}{l}\text { Mixture of } \mathrm{CH} \text { with pendant } \\
\text { methacrylate (CH-MA), } \mathrm{CH} \\
\text { with pendant methacrylate } \\
\text { and catechol (CH-MA-Cat), } \\
2,4,6- \\
\text { trimethylbenzoylphosphinate, } \\
\text { and } \mathrm{FeCl}_{3}\end{array}$ & $\begin{array}{l}\text { 2,4,6-trimethylbenzoylphosphinate } \\
\text { (LAP) }\end{array}$ & $\begin{array}{l}\text { FRP using Norrish } \\
\text { type I photoinitiator }\end{array}$ & 73 \\
\hline & & $\begin{array}{l}\text { Glycol chitosan modified } \\
\text { with pedant phenol groups }\end{array}$ & RuBi and SPS & $\begin{array}{l}\text { ET reaction using } \\
\text { Norrish type II } \\
\text { photoinitiator }\end{array}$ & 75 \\
\hline & $\begin{array}{l}\text { Chondroitin sulfate } \\
\text { (CS) Section 2.2.3 }\end{array}$ & $\begin{array}{l}\text { Methacrylate pendant CS } \\
\text { oxidized and mixed with } \\
\text { Irgacure } 2959 \text { and other } \\
\text { acrylates }\end{array}$ & Irgacure 2959 & $\begin{array}{l}\text { FRP using Norrish } \\
\text { type I photoinitiator }\end{array}$ & 78 \\
\hline & Dextran Section 2.2.4 & $\begin{array}{l}\text { Native or oxidized dextran } \\
\text { mixed with Gel, HEMA, or } \\
\text { catechol pendant multiarm } \\
\text { PEG }\end{array}$ & Irgacure 2959 & $\begin{array}{l}\text { FRP using Norrish } \\
\text { type I photoinitiator }\end{array}$ & $83-86$ \\
\hline & \multirow{2}{*}{$\begin{array}{l}\text { Hyaluronic acid (HA) } \\
\text { Section 2.2.5 }\end{array}$} & $\begin{array}{l}\text { Methacrylate pendant HA } \\
\text { mixed with type I and type } \\
\text { II initiators }\end{array}$ & $\begin{array}{l}\text { 2,2-dimethoxy-2-phenylacetephenone } \\
\text { or Irgacure } 2959 \text { or Eosin- } Y \text {, } \\
\text { 1-vinyl-pyrrilidinone, and TEA }\end{array}$ & $\begin{array}{l}\text { FRP using Norrish } \\
\text { type I or type II } \\
\text { photoinitiator }\end{array}$ & $63,89,90$ \\
\hline & & $\begin{array}{l}\text { 2-Nitrobenzaldehyde } \\
\text { conjugated HA mixed with } \\
\text { polymers with multiple } \\
\text { amine groups }\end{array}$ & 2-Nitrobenzaldehyde & $\begin{array}{l}\text { Schiff-base reaction } \\
\text { between the amine } \\
\text { and photo-released } \\
\text { benzaldehyde }\end{array}$ & $91-94$ \\
\hline Natural oil & Soybean oil Section 2.3 & $\begin{array}{l}\text { Melt copolyester with long } \\
\text { hydrocarbon from soy oil, } \\
\text { catechol, and coumarin }\end{array}$ & Coumarin & $\begin{array}{l}\text { Photodimerization of } \\
\text { coumarins }\end{array}$ & 96,97 \\
\hline
\end{tabular}

[a] All the gelation systems except natural oil-derived polymers contain water or organic solvent as a plasticizer for the facile delivery of adhesives to the target tissues. 


\section{Photoreactive Tissue Adhesives Derived from Naturally Occurring Polymers}

\subsection{Photoreactive Tissue Adhesives Derived from Naturally Occurring Proteins}

\subsubsection{Gelatin-Derived Photoreactive Tissue Adhesives}

Collagen is the most abundant protein in the mammalian body. The natural abundance of collagen makes it a suitable biomaterial with translational capability [32]. However, collagen is insoluble in most conditions and hard to process, limiting its applicability. Denatured collagen when extracted by acid (type A) or base conditioning followed by acid extraction (type B), produces gelatin [33]. Gelatin is biocompatible, inexpensive, and bioabsorbable, allowing it to be applicable in a wide range of biomedical applications such as drug delivery [34], bioprinting [35], and wound healing [36]. In early 1990, Matsuda et al. reported the development of a wide variety of photoreactive gelatin derivatives for tissue engineering applications $[17,21,37,38]$. The commonly used bovine bone-derived gelatin has $\sim 36$ lysine residues per molecule. Gelatin can be functionalized with photoactive groups such as thymine $(\mathrm{T})$, coumarin $(\mathrm{Cou})$, benzophenone $(\mathrm{BPh})$, and xanthene dyes $(\mathrm{X})$. When exposed to light, $\mathrm{T}$ (reaction light wavelength, $\left.\lambda_{\text {rxn }} \sim 280 \mathrm{~nm}\right)$, cinnamyl $\left(\lambda_{\text {rxn }} \sim 290 \mathrm{~nm}\right)$, and Cou $\left(\lambda_{\text {rxn }} \sim 320 \mathrm{~nm}\right)$ undergo [2 +2 ]-cycloaddition reactions. BPh $\left(\lambda_{\mathrm{rxn}} \sim 290 \mathrm{~nm}\right)$ and $X\left(\lambda_{\mathrm{rxn}} \sim 500 \mathrm{~nm}\right)$ are Norrish type II photoinitiators that when excited with light lead to the absorption of relatively labile protons (amines, coinitiator), forming free radicals. Such radicals can be used for the polymerization of acrylic, methacrylic, and styrenic compounds. Both the photodimerization and free radical polymerization reactions allow the photo-controlled formation of crosslinked networks, thereby modulating the cohesive interactions of the adhesive.

To test the tissue sealing capability, a mixture of benzophenone conjugated gelatin (Gel-BPh), xanthene dye conjugated gelatin (Gel-X) $(20 \mathrm{wt} \%)$, polyethyleneglycol diacrylate (PEGDA, $10 \mathrm{wt} \%$ ), ascorbic acid $(0.03 \mathrm{wt} \%)$, and saline water was prepared. The viscous solution was applied to a liver injury $(2 \times 2 \times 2 \mathrm{~mm})$ created in rats and photocured using a xenon lamp. The hydrogel formed from photoirradiation showed good adhesion (qualitative) to liver tissues and stopped bleeding. The maximum adhesion strength of around $15 \mathrm{kPa}$ to wet collagen films (representative of tissues) was later quantified for this system. Interestingly, after photoirradiation of the adhesive glue, the Gel-BPh and Gel-X based films were present on the liver surface even seven days after surgery, and only minor gel deformation and negligible necrosis were observed. From the histological analysis at the wound site, the infiltration of inflammatory cells was observed around the gel. One month after surgery, the gels had shrunk significantly and were infiltrated with a large number of inflammatory cells and connective tissues [17,37].

An alternative strategy to the two-component system (Gel-X and PEGDA) described above was demonstrated by Matsuda et al. [12,39]. In this study, gelatin was functionalized with pendant styrene groups (Gel-St). A three-component adhesive was created using Gel-St, PEGDA, and carboxylated camphorquinone (CQ, $\lambda_{\mathrm{rxn}} \sim 480 \mathrm{~nm}$, Norrish type II photoinitiator). When exposed to visible light, CQ excites and creates free radicals by absorbing an adjacent labile proton, which leads to the cross-polymerization of styrene and diacrylate groups, forming a cohesively strong hydrogel. The three-component adhesive showed stronger adhesion to wet collagen films compared to fibrin-based glue. In a later study, this technology was shown to be effective in the controlled delivery of therapeutics that inhibit tumor recurrence [39]. The gelatin-based adhesives showed an effective sealing of the rat abdominal aorta [12] and release of gemcitabine (anticancer drug) and adenovirus and showed inhibition of post-surgery tumor growth $[40,41]$.

Fancy et al. developed a visible light-mediated crosslinking reaction of the tyrosine groups found in proteins using a ruthenium $(\mathrm{Ru})$ metal complex with bipyridine (bpy) (Norrish type II mechanism) [19]. When exposed to $\lambda_{\text {rxn }} \sim 452 \mathrm{~nm}$, [Ru(II)(bpy) $\left.{ }_{3}\right]^{2+}$ transfers an electron to an adjacent persulfate. This electron transfer leads to the homolytic cleavage of peroxide bonds in the persulfate and forms a sulfate anion, sulfate radical, and Ru (III). A single electron transfer between $\mathrm{Ru}$ (III) and 
$o$-aromatic proton of phenol then occurs to form $\mathrm{Ru}$ (II) and a tyrosyl radical. The tyrosyl radical couples with the adjacent phenol at the ortho position, followed by the $o$-aromatic proton abstraction by the sulfate radical to form the di-tyrosine units. The intermolecular electron transfer process allows phenolic polymers to crosslink at a higher wavelength. Using this Ru-based di-tyrosine photochemistry, tyrosine-containing proteins and other polymers can be crosslinked.

Gelatin inherently has a low tyrosine content. Elvin et al. modified amino acids in animal-sourced gelatin using Bolton-Hunter reagent to increase the tyrosine content. The modified gelatin, $\left[\mathrm{Ru}(\mathrm{II})(\mathrm{bpy})_{3}\right]^{2+}$, and sodium persulfate (SPS) were dissolved in phosphate-buffered saline (PBS) at $\mathrm{pH} 7.4$ and crosslinked using a $460 \mathrm{~nm}$ light source. The adhesive was shown to adhere to bovine amnion (adhesion strength $\sim 110 \mathrm{kPa}$ ) and seal sheep lung incisions [42]. The bovine type A gelatin adhered to bovine amnion significantly better than commercial fibrin glue. The tissue adhesive was later used for repairing ileum defects in rabbits and canine colon anastomosis repair [43].

Liu et al. modified gelatin to have a higher phenolic content using two methods [44]. First, gelatin was conjugated with pendant catechol groups (Gel-Cat) using an amide bridge formed between the carboxylic acid groups of gelatin and amine groups in dopamine. Second, amide bonds were formed by the carbodiimide-mediated reaction of the pendant amine groups of gelatin and carboxylic groups of phloretic acid to derive gelatin with pedant phenol (Gel-Phe). Both Gel-Cat and Gel-Phe were crosslinked using Ru-based photochemistry. Compared to unmodified gelatin, Gel-Phe showed a higher adhesion strength (adhesion strength $\sim 77 \mathrm{kPa}$ ) to egg membranes. Meanwhile, Gel-Cat (adhesion strength $\sim 63 \mathrm{kPa}$ ) showed a similar adhesion strength to unmodified gelatin.

The amine pendant groups in gelatin, when reacted with methacrylic anhydride, form methacrylamide pendant gelatin (GelMA). Assman et al. reported the photopolymerization of GelMA using 2-hydroxy-4'-(2-hydroxyethoxy)-2-methylpropiophenone (Irgacure 2959) [45]. Irgacure 2959, a Norrish type I photoinitiator, when exposed to light $\left(\lambda_{\mathrm{rxn}} \sim 350 \mathrm{~nm}\right)$, undergoes homolytic bond cleavage and forms two free radicals that can initiate the polymerization of acrylates, methacrylates, and styrenes. In the case of GelMA, this polymerization leads to the formation of crosslinked networks due to intramolecular backbiting. GelMA of $10-25 \mathrm{wt} / \mathrm{vol} \%$ was mixed with Irgacure 2959 (0.5 wt/vol \%) in PBS buffer, and the viscous solution was tested for its wound closure adhesion strength (ASTM F2458-05) with porcine skin. The GelMA-based adhesives displayed lower wound closure adhesion strength compared to commercially available Progel ${ }^{\mathrm{TM}}$ (human serum albumin and a PEG crosslinker). However, in terms of the shear adhesion and burst pressure strength measurements, $25 \mathrm{wt} / \mathrm{vol} \%$ GelMA outperformed commercially available sealants such as Evicel ${ }^{\circledR}$, Progel $^{\mathrm{TM}}$, and Coseal ${ }^{\mathrm{TM}}$. To demonstrate the potential of GelMA as a surgical adhesive, its in vivo lung sealing capability in rat and pig models was also tested. GelMA sealant did not elicit an inflammatory host response and degraded with time after adequate wound healing. To avoid the usage of a UV light source that may cause tissue damage, Sani et al. created GelMA sealants that can be crosslinked using an alternative photochemistry [46]. A combination of Eosin-Y (Norrish type II, $\lambda_{\mathrm{rxn}} \sim 514 \mathrm{~nm}$ ), triethanolamine (TEA, coinitiator), and $N$-vinylcaprolactam (coinitiator) was used as the visible light photoinitiator system for crosslinking GelMA, and an antimicrobial peptide (Tet213) was added to the mixture to reduce the risk of infections at the place of injury. The antimicrobial GelMa adhesive showed stronger adhesion to porcine gingiva compared to commercially available Coseal ${ }^{\mathrm{TM}}$. Additionally, the GelMA sealant showed potential applications in treating perimplanting disease in rat calvarial defects (Figure 2) [46]. 

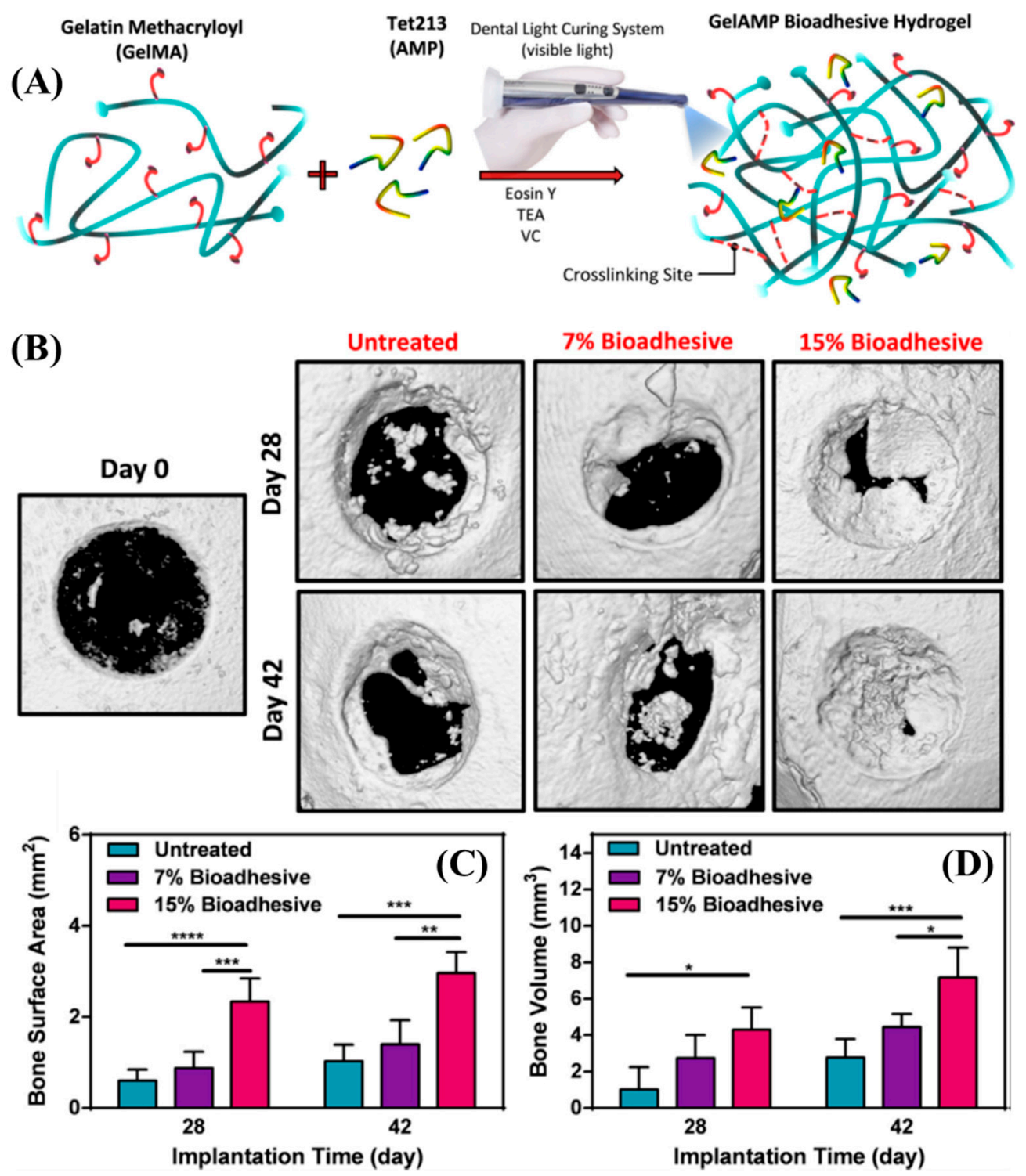

Figure 2. (A) Schematic representation of the modification, synthesis, and gelation of GelMA. (B) Representative micro-CT images for untreated defects and defects treated with $7 \%$ and $15 \%$ GelMA on Days 28 and 42 post-implantation. (C,D) Quantitative analysis of bone surface area (C) and bone volume (D) [46]. Copyright 2019, reproduced with permission from Elsevier Inc.

\subsubsection{Fibrinogen for Photoreactive Tissue Adhesives}

Fibrinogen is a glycoprotein complex commonly found in the blood of vertebrates. It is an active component in the blood coagulation cascade and wound healing [47]. During tissue injury, thrombin converts fibrinogen to fibrin and lead to a fibrin-blood clot [48]. Elvin et al. suggest that due to the propensity of fibrinogen to interact with other extracellular matrix proteins, fibrinogen-based sealants have the potential to become active hemostatic tissue adhesives [20]. Fibrinogen is rich in tyrosine, hence the Ru-based di-tyrosine photochemistry is effective for increasing the cohesive strength of the sealant. Fibrinogen photochemically crosslinked using Ru-based photochemistry (EXFO mercury light source, 400-500 $\mathrm{nm}$ internal filter, supplying output $\sim 10 \mathrm{~mW} / \mathrm{cm}^{2}$ ) shows strong adhesion to bovine amnion (adhesion strength $\sim 96 \mathrm{kPa}$ ) compared to Tisseel ${ }^{\mathrm{TM}}$ (adhesion strength $\sim 18 \mathrm{kPa}$ ). In a follow-up study, these photocrosslinked adhesives were used for sealing rat skin incisions and pig arterial wounds. The photocrosslinked fibrinogen showed hemostatic activity, and the results clearly 
showed that the crosslinked fibrinogen is safe, degrades with time, and effectively heals injured tissues including the skin and arteries [49].

\subsubsection{Recombinant Protein-Derived Photoreactive Tissue Adhesives}

Aquatic organisms such as mussels and sandcastle worms have perfected adhesion mechanisms to sustain their life underwater [50,51]. Mussels orchestrate a complex adhesion mechanism using a series of proteins secreted from their feet (MAPs) that allow them to cling onto surfaces residing underwater [52]. The adhesive behavior of MAPs is widely studied, and the strong adhesion strength is correlated to the covalent and non-covalent interactions offered by phenolic amino acid sequences such as tyrosine and 3,4-dihydroxyphenylalanine (DOPA) [53-55]. Using recombinant gene technology, Jeon et al. created a recombinant MAP (LAMBA) that contains $20 \mathrm{~mol} \%$ of tyrosine sequences [56]. Using the Ru-based di-tyrosine photochemistry, the aqueous solution (sodium acetate buffer, $\mathrm{pH}=5.5$ ) of LAMBA and photoinitiator was crosslinked using a LED dental curing lamp (460 nm, intensity at source $=1.2 \mathrm{~W} / \mathrm{cm}^{2} ;$ FORZA4) from a $20 \mathrm{~mm}$ distance. The LAMBA glue stopped the bleeding from open wounds created on the backs of rats within $60 \mathrm{~s}$ and induced negligible inflammation even after 14 days (Figure 3 ).

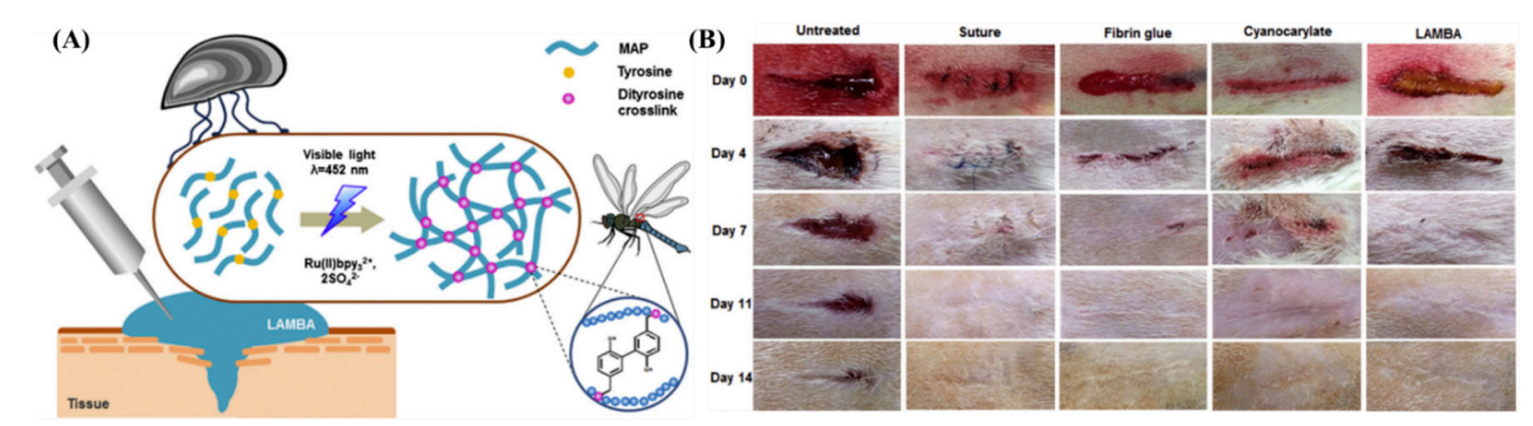

Figure 3. (A) Schematic representation of the mechanism of the recombinant MAP's adhesion. (B) Rat skin incisions imaged at different time frames subjected to no treatment, treated with suture, fibrin glue, cyanoacrylate, and LAMBA. Accelerated wound closure was observed for wounds treated with LAMBA [56]. Copyrights 2015, reproduced with permission from Elsevier Ltd.

Tropoelastin is a precursor of elastin and is one of the most abundant proteins found in mammalian skin. Tropoelastin contains various cell-binding sites that may promote cellular adhesion and growth [57]. Annabi et al. fabricated photocrosslinkable adhesives derived from recombinant tropoelastin [58]. Tropoelastin was modified to have pendant methacrylamide functional groups (MeTro) using a similar chemistry to derive GelMA from gelatin as described in Section 2.1.1. The solution of $5-20 \mathrm{wt} / \mathrm{vol} \%$ of MeTro and $0.5 \mathrm{wt} / \mathrm{vol} \%$ Irgacure 2959 becomes elastic and adhesive when exposed to UV light $\left(\lambda=360-480 \mathrm{~nm}\right.$, intensity $\left.=6.9 \mathrm{~mW} / \mathrm{cm}^{2}\right)$. Compared to commercially available tissue adhesives such as Evicel ${ }^{\circledR}$, Coseal $^{\mathrm{TM}}$, and Progel ${ }^{\mathrm{TM}}$, MeTro-based glues show remarkable adhesion strength and burst pressure during ex-vivo tests. The MeTro glue was shown to be effective in sealing lung incisions created in porcine animal models. In a follow-up study, Annabi et al. used a combination of GelMA and MeTro encapsulated with Tet213 to create a sprayable and antimicrobial tissue adhesive [59]. The adhesive was crosslinked using an Eosin-Y based photoinitiating system as described elsewhere [46]. The negligible inflammatory response after the subcutaneous implantation of the adhesive in rats showed the biocompatibility of the hydrogel created from the combination of MeTro and GelMA. 


\subsection{Photoreactive Tissue Adhesives Derived from Polysaccharides}

\subsubsection{Alginate-Derived Photoreactive Tissue Adhesives}

Alginate (Alg) is a commonly found block copolymer in brown algae made from 1-4 linked $\beta$-D-mannuronic acid and $\alpha$-L-guluronic acid [60]. Alginate-based materials are cheap to produce, show biocompatibility, and are used for cell immobilization [61] and protein encapsulation [62]. Smeds et al. converted $6 \mathrm{~mol} \%$ of the free hydroxyl groups present in alginate to methacrylate (Alg-MA) by reaction with methacrylic anhydride in basic conditions [63]. A visible light-active Eosin-Y, TEA, and 1-vinyl-pyrrolidinone based Norrish type II visible light initiating system was used for curing the Alg-MA. The Alg-MA hydrogel network was demonstrated as a sealant for repairing corneal perforations. Recently, using a similar gelation mechanism, the adhesion of Alg-MA to biological tissues was examined by Charron et al. [64]. Alg-MA-derived hydrogels showed poor adhesion strength to wet tissues. To improve the adhesion, Alg-MA was oxidized using sodium periodate. The oxidation improved the interfacial interaction between Alg-MA and tissue surfaces, as indicated by the change in the mode of failure from adhesive to cohesive upon oxidation. The aldehyde groups formed from the oxidation of the polysaccharide backbone are hypothesized to react with the amine groups on the tissue proteins.

\subsubsection{Photoreactive Tissue Adhesives Derived from Chitosan}

Chitin is a polysaccharide found in the exoskeletons of arthropods. Chitin is highly insoluble and hard to process. Chitosan is obtained by the deacetylation of the $N$-acetyl groups in chitin [65]. The cationic groups in chitosan are proposed to enable the penetration of chitosan into negatively charged tissue surfaces [66]. Ono et al. synthesized chitosan with pendant benzyl azide groups using the carbodiimide-mediated amidation of the primary amines in chitosan and 4-azidobenzoic acid (Figure 4A) [67]. When exposed to $\lambda_{\text {rxn }} \sim 254 \mathrm{~nm}$ (power $=4 \mathrm{~W}, 2 \mathrm{~cm}$ from the source), the benzyl azide groups release nitrogen through an intramolecular rearrangement and form reactive nitrene groups. The nitrene groups can undergo homodimerization and react with primary and secondary amine groups. The strategy is proposed to increase the cohesive strength of the adhesive by the reaction between the light-derived nitrene groups and primary amines found in chitosan. Additionally, the amine groups present on the tissue surface can also react with the adhesive to augment the interfacial bonding strength. Chitosan is a solid material with poor water solubility, which makes it cumbersome to deliver uniformly over tissue surfaces without the assistance of a plasticizer. In the same study, the authors modified the free amine groups of chitosan using lactobionic acid to improve the water solubility. A $30 \mathrm{mg} / \mathrm{mL}$ solution of $2 \%$ lactobionic acid and $2 \%$ azidobenzoic acid (Az-CH-LA) cured using UV-B light showed significantly higher sealing strength than fibrin glue when applied ex-vivo for sealing pinholes created in the porcine aorta and small intestine. In a follow-up study, Ishihara et al. administered the Az-CH-LA hydrogels for sealing a pinhole (1.2 mm diameter) in a rabbit aorta [68]. The hydrogels remained intact on the aorta for at least 30 days in the live animal and were covered by fibrous connective tissues and inflammatory cells. Some of the hydrogels were found to be phagocytosed by the macrophages. Az-CH-LA was also shown to induce hemostasis and accelerate wound healing in live mouse models [69]. In the early epidermal wound healing phases, the Az-CH-LA hydrogel induced a significant wound contraction, with more than $50 \%$ wound closure (Figure 4B) [70]. 
(A)

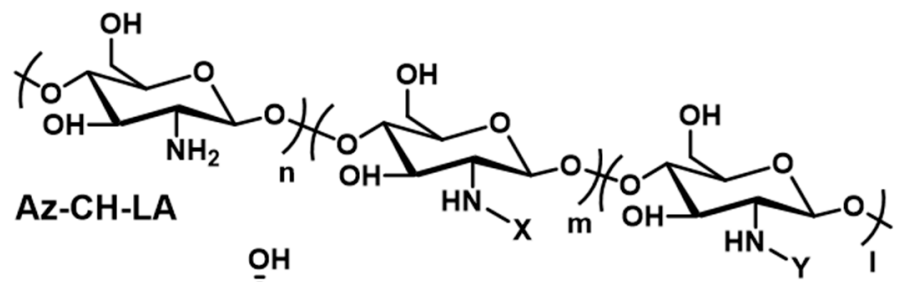<smiles>CC(=O)[C@H](O)C(O)[C@H](O[C@H]1O[C@H](CO)[C@@H](O)[C@H](O)[C@H]1O)[C@@H](O)CO</smiles><smiles>CC(=O)c1ccc([N+](=O)[O-])cc1</smiles>

$\mathrm{X}=$ Lactobionic acid

$\mathrm{Y}=\boldsymbol{p}$-azidobenzoic acid

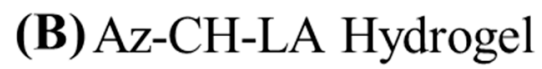

Control
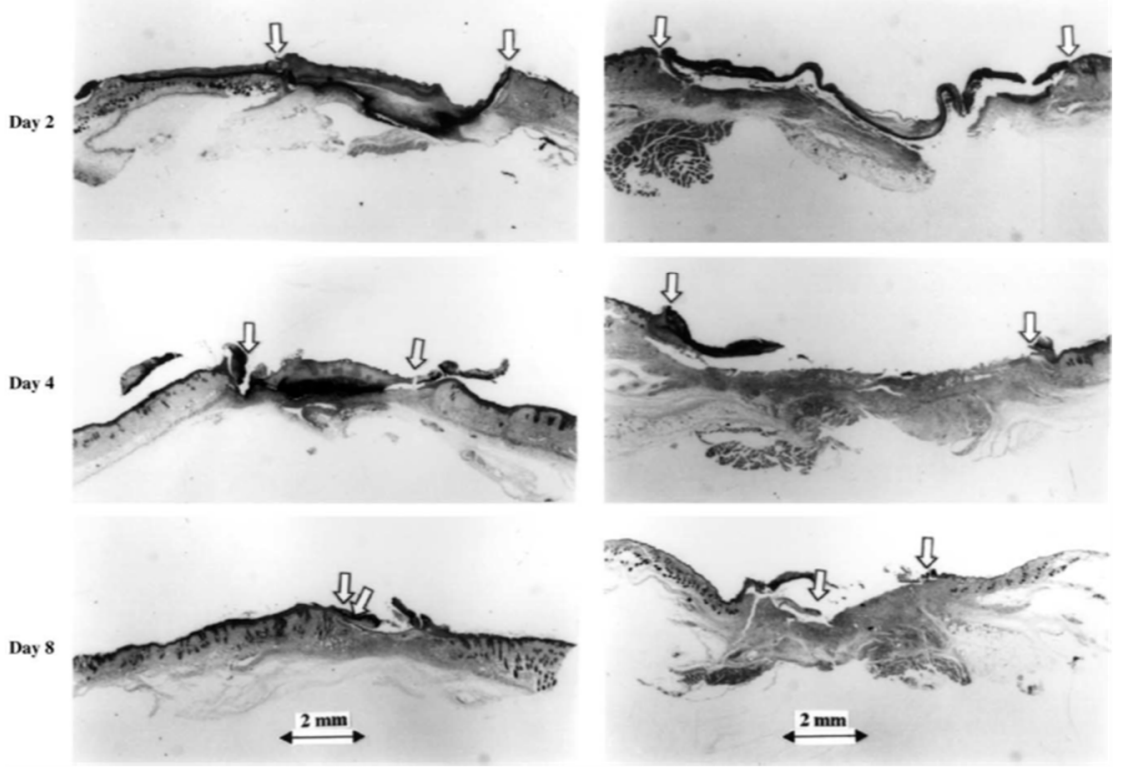

Figure 4. (A) Schematic representation of the chemical structure of Az-CH-LA [67]. (B) Histological examination of wound repair of Az-CH-LA hydrogel-treated (left) and control wounds (right) [69]. Copyright 2001, reproduced with permission from Elsevier.

The thiol-ene reaction is a high yield Michael addition reaction between thiols and activated alkenes and can be initiated with light and a photoinitiator. The free radical produced from the photoreaction can result in a sulfur centered radical that reacts with activated alkenes such as acrylates and acrylamides. Chitosan with pendant thiol groups was synthesized using a carbodiimide-mediated amidation reaction with $N$-acetylcysteine [71]. A hydrogel network was created by photoirradiating $\left(\lambda_{\text {rxn }}=365 \mathrm{~nm}\right.$, intensity $\left.=15 \mathrm{~mW} / \mathrm{cm}^{2}\right)$ the mixture of thiol pendant chitosan, PEG-dimethacrylate, and Irgacure 2959. The formed hydrogels showed an adhesion strength of $\sim 50 \mathrm{kPa}$ to porcine skin with minimum cytotoxicity. With the increase in free thiol groups, a higher adhesion strength was observed, suggesting that the thiol groups in the hydrogels may undergo interfacial reactions with the proteins in the tissue.

Dual networks (DN) allow the formation of hydrogels with higher toughness than the single network without sacrificing the softness of the material [72]. Wang et al. created DN from chitosan modified with two different modifications [73]. First, a methacrylamide pendant chitosan (CH-MA) was created using similar chemistry with methacrylic anhydride as described in Section 2.1.1. 
Second, some of the amine groups in $\mathrm{CH}-\mathrm{MA}$ were modified to have pendant catechols using a Schiff-base reaction with 3,4-dihydoxybenzaldehyde (CH-MA-Cat). CH-MA, CH-MA-Cat, lithium phenyl-2,4,6-trimethylbenzoylphosphinate (LAP, Norrish type I initiator, $\lambda_{\mathrm{rxn}} \sim 390 \mathrm{~nm}$ ), and $\mathrm{FeCl}_{3}$ were mixed and photoirradiated (400-500 nm band-pass filter at $50 \mathrm{~mW} / \mathrm{cm}^{2}$ for $30 \mathrm{~s}$ ) to create the DN adhesive network. The coordination bonds between Fe (III) and catechol in the covalently crosslinked network are proposed to act as sacrificial interactions that dissipate the mechanical forces on the adhesive. The DN showed $\sim 18 \mathrm{kPa}$ lapshear adhesion strength when applied on porcine skin. The hemostatic efficiency and wound healing were studied using the mouse liver puncture assay and subcutaneous wound healing model, respectively. The chitosan-based DN hydrogels showed $\sim 8$-fold less blood loss compared to untreated controls. The antibacterial activity of chitosan improved the healing rate of S. aureus-infected subcutaneous wounds in mice treated with the DN adhesive network compared to the PBS buffer treated variant.

To improve the water solubility and accelerate the use of chitosan-based materials for biomedical applications, glycol chitosan (G-CH) is commonly used as an alternative to chitosan [74]. G-CH is a derivative of $\mathrm{CH}$ with the primary hydroxyl groups of each sugar unit modified to ethylene glycol units. Using an $\mathrm{N}$-3-dimethylaminopropyl- $\mathrm{N}$-ethylcarbodiimide hydrochloride (EDC)-based coupling reaction between the amine groups of G-CH and carboxylic acid groups of phloretic acid, Lu et al. [75]. conjugated phenol pendant groups to glycol chitosan. The phenol pendant glycol chitosan was photochemically crosslinked using a Ru-based di-tyrosine chemistry described elsewhere [19]. The formed hydrogels were tested for hemostatic activity using a mouse liver puncture test. A 3-fold reduction in blood loss was observed compared to the control with no treatment. In the same study, authors encapsulated the hydrogel with amoxicillin and demonstrated that the hydrogel can prevent bacterial infections at the wound site.

\subsubsection{Photoreactive Tissue Adhesives Derived from Chondroitin Sulfate}

Chondroitin sulfate (CS) is a glycosaminoglycan composed of alternating $N$-acetylgalactosamine and glucuronic acid. CS acts as a compression resistance material in cartilage [76]. Materials developed from CS have demonstrated anti-inflammatory activity and decrease the friction between tissues [21,77]. Wang et al. modified the hydroxyl groups of CS to methacrylate groups (CS-MA) by a nucleophilic ring opening of the epoxy group of glycidyl methacrylate with the primary hydroxyl groups of CS. The backbone of CS-MA was then oxidized to aldehyde groups using sodium periodate to generate oxCS-MA [78]. oxCS-MA was designed to bridge the interface between the PEG hydrogel or poly(2-hydroxyethylmethacrylate) (poly(HEMA)) and cartilage. First, a layer of oxCS-MA was applied to cartilage and equilibrated for $5 \mathrm{~min}$ and then the weakly adsorbed oxCS-MA was washed away using PBS buffer, and the mixture of HEMA and Irgacure 2959 dissolved in PBS buffer was applied on the cartilage and photopolymerized before the measurement of adhesive performance. This CS-based system showed a tack adhesion strength of $\sim 45 \mathrm{kPa}$. The methacrylate group of oxCS-MA polymerizes with HEMA, while the aldehyde groups of oxCS-MA were proposed to undergo Schiff-base reactions with the primary amine groups in the cartilage, resulting in a strong bridge at the implant-cartilage interface.

\subsubsection{Photoreactive Tissue Adhesives Derived from Dextran}

Dextran is a polysaccharide with linear $\alpha-1,6$-glucosidic linkages and branching via 1,3 linkages [79]. Dextran-based materials have demonstrated potential applications in therapeutic delivery [80], plasma volume expansion [81], and thrombolysis prevention [82]. To create dextran-based photocrosslinkable tissue adhesives, a urethane bridge was created by the condensation reaction between dextran hydroxyl groups and 2-isocyanatoethylmethacrylate [83]. The condensation product Dex-MA was mixed with Irgacure 2959 in DMSO and applied between gelatin-coated glass slides and photocrosslinked (UV light $320-480 \mathrm{~nm}$, intensity $30 \mathrm{~mW} / \mathrm{cm}^{2}$ ). With the increase in the substitution of hydroxyl groups with methacrylate, the water solubility of dextran derivatives decreased and 
the adhesion strength to gelatin-coated glass slides increased from 1.5 to $3 \mathrm{MPa}$. To improve the adhesive performance, in a follow-up study, Wang et al. further modified Dex-MA by oxidizing the polysaccharide backbone to aldehyde groups and feeding gelatin in the adhesive solution (oxDex-MA-Gel) [84]. The oxidation of the dextran and incorporation of gelatin significantly improved the cohesive and adhesive strength of the formulation. Compared to the previous generation, a 1.5-fold increase in adhesion was observed in this oxDex-MA-Gel design. To further improve the adhesion strength and accelerate the curing time, HEMA was mixed with Dex-MA along with Irgacure 2959 [85]. A maximum adhesion strength of $\sim 4.3 \mathrm{MPa}$ was obtained with the incorporation of HEMA into Dex-MA. As an alternate strategy, 3-armed PEG modified with catechol was blended with Dex-MA, and the adhesion was improved by $~ 1.5$-fold compared with Dex-MA photocrosslinked alone [86]. When exposed to air for $72 \mathrm{~h}$, the catechol molecules oxidized and further crosslinked to give a significantly improved adhesion of $\sim 6 \mathrm{MPa}$.

\subsubsection{Photoreactive Tissue Adhesives Derived from Hyaluronic Acid}

Hyaluronic acid is a mucopolysaccharide with alternating $\beta$-D-N-acetylglucosamine and $\beta$-D-glucuronic acid [87]. Hyaluronic acid (HA) has crucial roles in many cellular functions, and HA-derived materials have been used in the clinic for decades [88]. In the early 2000s, two independent studies by Grinstaff et al. reported the development of adhesive hydrogels from methacrylate pendant hyaluronic acid (HA-MA) photocrosslinked using two different photoinitiators [63,89]. The first photoinitiator systems consisted of Eosin- $Y$, 1-vinyl-pyrrilidinone, and TEA with an argon laser $(\lambda=514 \mathrm{~nm})$, and the second comprised of 2,2-dimethoxy-2-phenylacetephenone and a UV light source $(\lambda=254 \mathrm{~nm})$. Both photoinitiating systems showed a similar qualitative efficacy in sealing the corneal tissues [63]. A later study with an argon laser-based gelation system (intensity $=200 \mathrm{~mW} / \mathrm{cm}^{2}$ ) showed corneal wound closing capability while maintaining normal and stable intraocular pressure (IOP). The stromal cells established new connective tissues with the HA-MA based adhesive. The HA-MA hydrogel was ejected out from the corneal wound as the healing occurred in a rabbit corneal wound model [89]. Chandrasekharan et al. have used HA-MA photocrosslinked using Irgacure $2959\left(\lambda=320-500 \mathrm{~nm}\right.$, intensity $\sim 30 \mathrm{~mW} / \mathrm{cm}^{2}$, OmniCure S1500) for ex-vivo skin wound closure analysis [90]. It was observed that the HA-MA hydrogels prepared from higher concentrations of HA-MA exhibited strong adhesion (adhesion strength $\sim 13 \mathrm{kPa}$ ) to the porcine skin for several weeks.

Yang et al. modified carboxylic acid groups in the HA backbone to 2-nitrobenzyl alcohol (HA-oNB) [91]. When exposed to $\lambda_{\mathrm{rxn}} \sim 377 \mathrm{~nm}$, the oNB groups undergo intramolecular rearrangement to form 2-nitrobenzaldehyde. When HA-oNB was mixed with a polymer that contained multiple amine groups and irradiated, a Schiff-base reaction occurred between the photo-derived aldehydes and amines. This strategy allows a phototriggered-iminecrosslinking (PIC) reaction (Figure 5A). Several amine-containing polymers such as G-CH, polyethyleneimine, $\varepsilon$-poly(L-lysine), bovine serum albumin, and platelet-rich plasma (PRP) were used as the nucleophilic crosslinkers for PIC. The HA-oNB photocrosslinked $\left(\lambda=365 \mathrm{~nm}\right.$, intensity $=30 \mathrm{~mW} / \mathrm{cm}^{2}$, time of exposure $\left.=3 \mathrm{~min}\right)$ with G-CH showed a lapshear adhesion strength of $\sim 40 \mathrm{kPa}$ to porcine casing. An in vivo rat dorsal skin repair model was used to investigate the potential tissue repair capability of PIC (Figure 5B,C). A faster 7-day wound healing was observed for the PIC-based crosslinking network compared to saline water control. In a follow-up study, Liu et al. utilized HA-oNB photocrosslinked with PRP for cartilage repair [92]. The in vitro studies showed that this system could promote the proliferation and migration of chondrocytes and bone marrow stem cells. In vivo testing using the rabbit cartilage defect model demonstrated that HA-oNB-PRP has better cartilage regeneration efficacy when using thrombin-activated PRP gel. The PIC-network created by oNB pendant carboxymethyl cellulose (CMC) and G-CH were used as a postoperative antiadhesion barrier in the rat abdomen. The results of an in vivo rat model experiment confirm that this PIC-network effectively reduces the adhesion between abdominal tissues and may reduce the postoperative complications during abdominal surgeries [93]. 

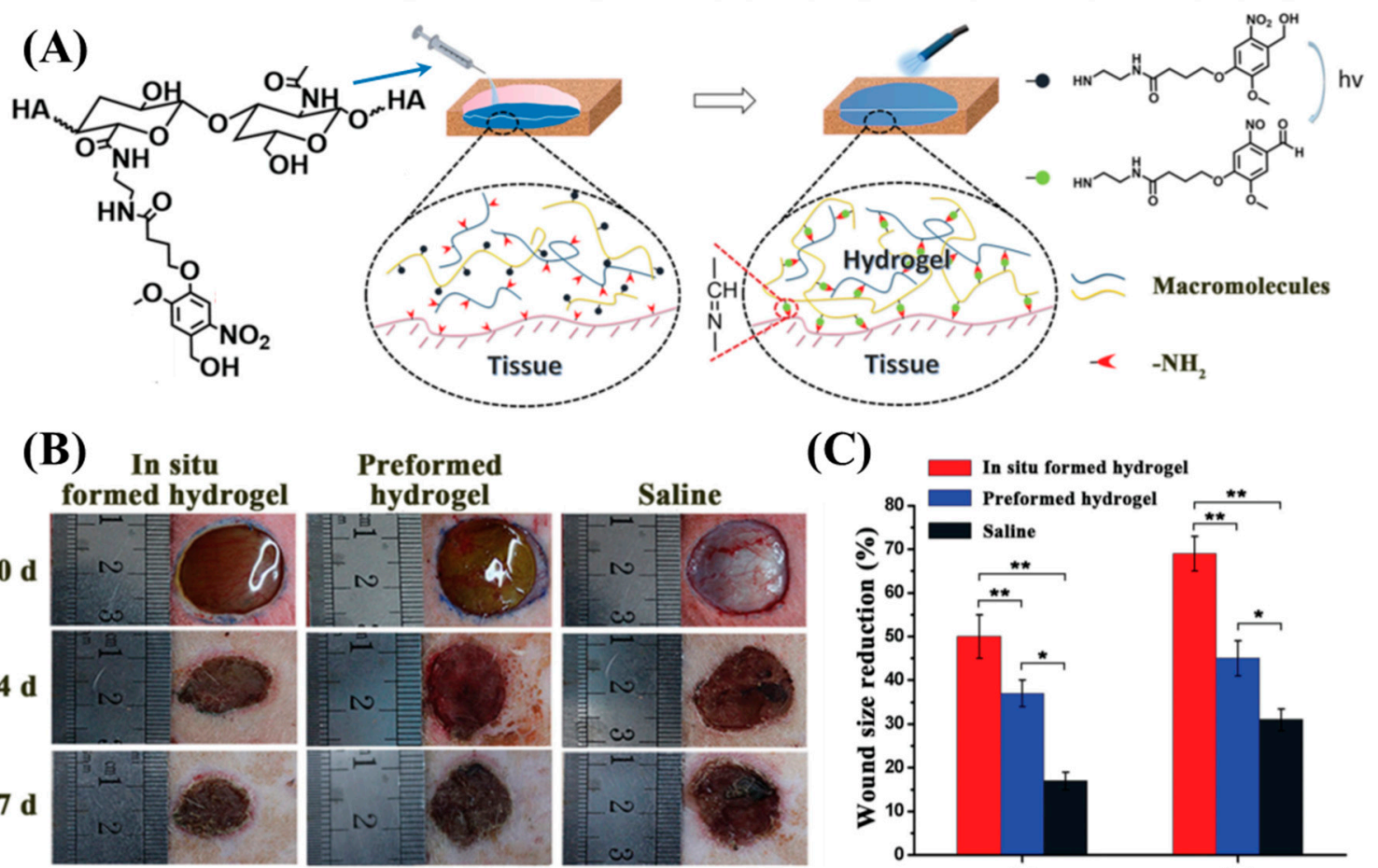

(C)

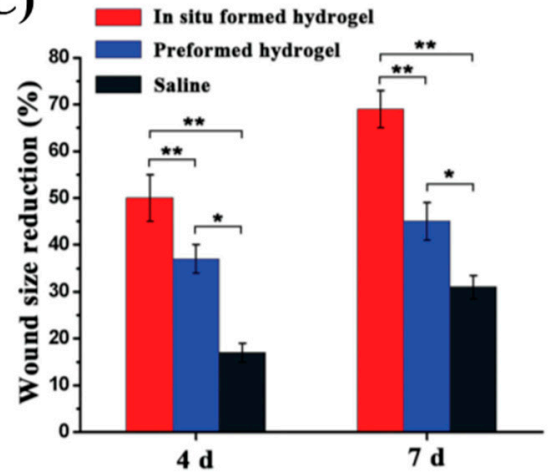

Figure 5. (A) Schematic representation of the phototriggered-iminecrosslinking (PIC) and adhesion mechanism of HA-oNB. (B) Photographs of subcutaneous wounds created on the backs of rats at treated with HA-oNB and controls. (C) Quantitative wound size reduction comparison between the three groups, indicating superior wound healing performance by in situ formed HA-oNB hydrogel [91]. Copyright 2016, reproduced with permission from WILEY-VCH Verlag GmbH \& Co. KGaA, Weinheim.

Hong et al. demonstrated a combination of two different photochemistries to develop DN hydrogels as tissue adhesive materials [94]. The first component is HA-oNB and the second component is a mixture of GelMA and a photoinitiator (LAP). Upon exposure to light, GelMA starts polymerizing and creates a crosslinked material while HA-oNB forms aldehyde groups that are expected to react with amine groups on the GelMA and tissue surface. This DN hydrogel provides both adhesive and cohesive control with light. The DN hydrogel was demonstrated to stop bleeding from pig carotid arteries and heart. The injured pigs survived after hemostatic treatments with this hydrogel, demonstrating the clinical potential of DN hydrogel as a traumatic wound sealant.

\subsection{Natural Oil-Derived Photoreactive Tissue Adhesives}

Oils derived from corn, soybeans, and coconuts are triglycerides with long hydrocarbon chains. Such oils are inexpensive and biorenewable [95]. The transamidation reaction between soybean oil and diethanolamine creates $\mathrm{N}$-aliphatic diethanolamide (Soy-diol). Xu et al. created copolyesters by the carbodiimide-mediated polyesterification reaction of Soy-diol, coumarin diol, and catechol diol with sebacic acid (diacid) [96]. The studies reviewed in the previous sections use water or organic solvents to facilitate the spreading of the adhesive, which may cause dehydration-induced compression or the production of leachable small molecules at the site of application. The Soy-diol enriched copolyesters show low viscosity and hydrophobicity that allow the copolyesters to spread to substrates submerged underwater without any organic solvents or plasticizers. Narayanan et al. evaluated the tissue adhesive behavior of the soybean oil-derived copolyesters (Figure 6A) [97]. Tissues derived from the porcine skin, heart, and liver were submerged in PBS buffer, the adhesive was brought in contact, and the area of contact was subjected to photoirradiation $\left(\lambda_{\mathrm{rxn}}=340 \mathrm{~nm}\right.$, intensity $=50 \mathrm{~mW} / \mathrm{cm}^{2}$, time of exposure $=5 \mathrm{~min}$ ). When exposed to $\lambda_{\mathrm{rxn}} \sim 340 \mathrm{~nm}$, two coumarin units undergo [2+2] intermolecular photocycloaddition. The dimerization of coumarin increases the cohesive strength 
of the copolyesters and induces strong adhesion to biological tissue surfaces submerged in aqueous media. A detailed investigation of the relationship between polymer structure and tissue adhesion is described in the study by characterizing the interfacial properties of the copolyesters and tissues. The authors propose that the low viscosity of the adhesive is a crucial parameter to enable adhesion to internal organs compared to the skin, because the internal tissue surfaces are rich in water compared to the skin (Figure 6B).

(A)

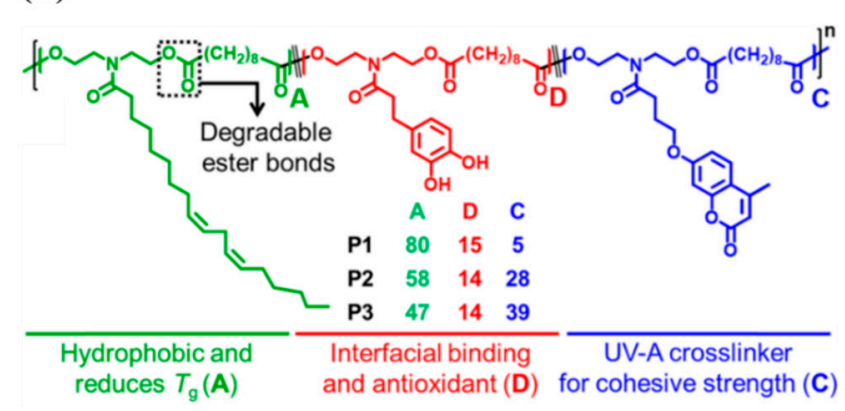

(B)

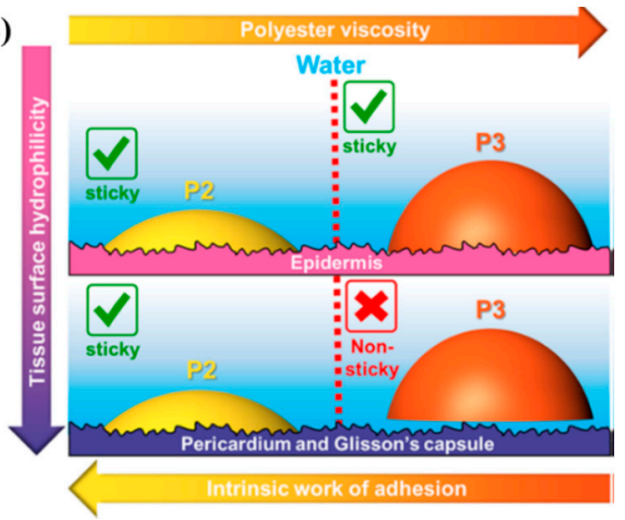

Figure 6. (A) Schematic representation and chemical composition of the soybean oil-derived photocrosslinkable polyester adhesives and (B) the origin of the tissue-specific adhesion observed in the polyesters. The polyester with a higher viscosity (P3) does not adhere to tissue surfaces with higher water content such as the heart and liver [97]. Copyright 2019, reproduced with permission from the American Chemical Society.

\section{Conclusion and Future Perspectives}

In conclusion, naturally derived photoreactive adhesives that demonstrate tissue adhesive behavior are summarized in this review. A wide diversity of proteins, polysaccharides, and oils are used for creating tissue adhesives due to their cost effectiveness, biocompatibility, and bioabsorption. The photochemistry allows these adhesives to have temporal and spatial control over the adhesive and cohesive strengths, which can minimize tissue damage. Several of the photoreactive adhesives show promising results for preventing hemorrhage, providing therapeutic delivery, and accelerating tissue regeneration at wound sites.

The field of photoreactive adhesives derived from natural resources is a rapidly growing research area. A plethora of applications are foreseen with the newly developed tissue adhesives in biomedical engineering and bioelectronics. Certainly, the photoreactive tissue adhesives distinguish themselves due to the temporal and spatial control over their adhesion strengths and mechanical properties. With the identification of new chemistries as potential photochemistries for the activation of tissue adhesives, some of the outstanding challenges in developing photoreactive tissue adhesives are resolved. For example, several of the photoactivations of natural tissue adhesive polymers rely on the photoactivated free radical polymerization of pendant functionalized naturally derived macromolecules. The reactive oxygen species created during this process are a major concern in inducing toxicity to the applied area. Additionally, the small molecule photoinitiators such as Irgacure 2959 and LAP that leach from the crosslinked matrix over time may cause allergic reactions or toxicity. However, photochemistries based on benzyl azide, coumarin, and 2-nitrobenzyl alcohol provides an alternative strategy since their photoreactions are radical-free and do not require leachable small molecule photoinitiators.

The environments of different tissues and their healing rates can be different. An adhesive that adheres to different types of tissue with tunable degradation should be considered to overcome this challenge. Though some of the limiting factors were overcome recently, the translation of these new 
materials from the lab to the clinic remains challenging. The testing of the feasibility of photoreactive tissue adhesives by surgeons might overcome this barrier and lead to fruitful translation into the clinic.

Author Contributions: A.N. wrote the original draft. Y.X., A.D., and A.J. reviewed, edited and reorganized the manuscript. All authors have read and agreed to the published version of the manuscript.

Funding: Authors acknowledge funding from the National Science Foundation (NSF) (DMR Awards 1508440 and DMR 1610483).

Conflicts of Interest: Authors declare no conflict of interest.

\section{References}

1. Hall, M.J.; Schwartzman, A.; Zhang, J.; Liu, X. Ambulatory Surgery Data from Hospitals and Ambulatory Surgery Centers: United States, 2010. Natl. Health Stat. Rep. 2017, 102, 1-15.

2. Forsch, R. Essentials of skin laceration repair. Am. Fam. Physician 2008, 78, 945-951. [PubMed]

3. Owen, J.; Andrews, W.W. Wound Complications after Cesarean Sections. Clin. Obstet. Gynecol. 1994, 37, 842-855. [CrossRef] [PubMed]

4. Tsao, S.; Tsao, H.; Henry, F.P.; Kochevar, J.; Redmond, R.; Kochevar, I.; Yao, M.; Zhao, Y. Light-activated tissue bonding for excisional wound closure: A split-lesion clinical trial. Br. J. Dermatol. 2012, 166, 555-563. [CrossRef] [PubMed]

5. Xu, N.; Yao, M.; Farinelli, W.; Hajjarian, Z.; Wang, Y.; Redmond, R.W.; Kochevar, I.E. Light-activated sealing of skin wounds. Lasers Surg. Med. 2014, 47, 17-29. [CrossRef] [PubMed]

6. Spotnitz, W.D. Hemostats, sealants, and adhesives: A practical guide for the surgeon. Am. Surg. 2012, 78, 1305-1321.

7. Coselli, J.S.; Bavaria, J.E.; Fehrenbacher, J.; Stowe, C.L.; Macheers, S.K.; Gundry, S.R. Prospective randomized study of a protein-based tissue adhesive used as a hemostatic and structural adjunct in cardiac and vascular anastomotic repair procedures. J. Am. Coll. Surg. 2003, 197, 243-252. [CrossRef]

8. Schenk, W.G.; Spotnitz, W.D.; Burks, S.G.; Lin, P.H.; Lin, P.; Lumsden, A.B. Absorbable cyanoacrylate as a vascular hemostatic sealant: A preliminary trial. Am. Surg. 2005, 71, 658-661.

9. LeMaire, S.A.; Carter, S.A.; Won, T.; Wang, X.; Conklin, L.D.; Coselli, J.S. The Threat of Adhesive Embolization: BioGlue Leaks through Needle Holes in Aortic Tissue and Prosthetic Grafts. Ann. Thorac. Surg. 2005, 80, 106-111. [CrossRef]

10. Alameddine, A.; Alimov, V.K.; Rousou, J.A.; Freeman, J. Aorto-Pulmonary Artery Disruption Following Acute Type-A Aortic Dissection Repair with the Use of BioGlue. J. Card. Surg. 2012, 27, 371-373. [CrossRef]

11. Spotnitz, W.D.; Burks, S. Hemostats, sealants, and adhesives III: A new update as well as cost and regulatory considerations for components of the surgical toolbox. Transfusion 2012, 52, 2243-2255. [CrossRef] [PubMed]

12. Li, C.; Sajiki, T.; Nakayama, Y.; Fukui, M.; Matsuda, T. Novel visible-light-induced photocurable tissue adhesive composed of multiply styrene-derivatized gelatin and poly(ethylene glycol) diacrylate. J. Biomed. Mater. Res. 2003, 66, 439-446. [CrossRef]

13. O’Rorke, R.; Pokholenko, O.; Gao, F.; Cheng, T.; Shah, A.; Mogal, V.; Steele, T.W.J. Addressing Unmet Clinical Needs with UV Bioadhesives. Biomacromolecules 2017, 18, 674-682. [CrossRef] [PubMed]

14. Feng, G.; Djordjevic, I.; Mogal, V.; O’Rorke, R.; Pokholenko, O.; Steele, T.W.J. Elastic Light Tunable Tissue Adhesive Dendrimers. Macromol. Biosci. 2016, 16, 1072-1082. [CrossRef]

15. Kloxin, A.M.; Kasko, A.M.; Salinas, C.N.; Anseth, K.S. Photodegradable Hydrogels for Dynamic Tuning of Physical and Chemical Properties. Science 2009, 324, 59-63. [CrossRef] [PubMed]

16. Evans, M.G.; Santappa, M.; Uri, N. Photoinitiated free radical polymerization of vinyl compounds in aqueous solution. J. Polym. Sci. 1951, 7, 243-260. [CrossRef]

17. Nakayama, Y.; Matsuda, T. Newly Designed Hemostatic Technology Based on Photocurable Gelatin. ASAIO J. 1995, 41, M374-M378. [CrossRef]

18. Lang, N.; Pereira, M.J.; Lee, Y.; Friehs, I.; Vasilyev, N.V.; Feins, E.N.; Ablasser, K.; O'Cearbhaill, E.; Xu, C.; Fabozzo, A.; et al. A Blood-Resistant Surgical Glue for Minimally Invasive Repair of Vessels and Heart Defects. Sci. Transl. Med. 2014, 6, 218ra6. [CrossRef]

19. Fancy, D.A.; Kodadek, T. Chemistry for the analysis of protein-protein interactions: Rapid and efficient cross-linking triggered by long wavelength light. Proc. Natl. Acad. Sci. USA 1999, 96, 6020-6024. [CrossRef] 
20. Elvin, C.M.; Brownlee, A.G.; Huson, M.G.; Tebb, T.A.; Kim, M.; Lyons, R.E.; Vuocolo, T.; Liyou, N.E.; Hughes, T.; Ramshaw, J.A.M.; et al. The development of photochemically crosslinked native fibrinogen as a rapidly formed and mechanically strong surgical tissue sealant. Biomaterials 2009, 30, 2059-2065. [CrossRef]

21. Matsuda, T.; Moghaddam, M.J.; MlWA, H.; Sakurai, K.; Iida, F. Photoinduced Prevention of Tissue Adhesion. ASAIO J. 1992, 38, M154-M157. [CrossRef] [PubMed]

22. Winkler, J.D.; Bowen, C.M.; Liotta, F. [2 + 2] Photocycloaddition/Fragmentation Strategies for the Synthesis of Natural and Unnatural Products. Chem. Rev. 1995, 95, 2003-2020. [CrossRef]

23. Maddipatla, M.V.S.N.; Wehrung, D.; Tang, C.; Fan, W.; Oyewumi, M.O.; Miyoshi, T.; Joy, A. Photoresponsive Coumarin Polyesters That Exhibit Cross-Linking and Chain Scission Properties. Macromolecules 2013, 46, 5133-5140. [CrossRef]

24. Nair, L.S.; Laurencin, C.T. Biodegradable polymers as biomaterials. Prog. Polym. Sci. 2007, 32, $762-798$. [CrossRef]

25. Sionkowska, A. Current research on the blends of natural and synthetic polymers as new biomaterials: Review. Prog. Polym. Sci. 2011, 36, 1254-1276. [CrossRef]

26. Duarte, A.P.; Coelho, J.F.J.; Bordado, J.; Cidade, M.T.; Gil, M.H. Surgical adhesives: Systematic review of the main types and development forecast. Prog. Polym. Sci. 2012, 37, 1031-1050. [CrossRef]

27. Scognamiglio, F.; Travan, A.; Rustighi, I.; Tarchi, P.; Palmisano, S.; Marsich, E.; Borgogna, M.; Donati, I.; De Manzini, N.; Paoletti, S. Adhesive and sealant interfaces for general surgery applications. J. Biomed. Mater. Res. Part B Appl. Biomater. 2015, 104, 626-639. [CrossRef]

28. Bré, L.P.; Zheng, Y.; Pêgo, A.P.; Wang, W. Taking tissue adhesives to the future: From traditional synthetic to new biomimetic approaches. Biomater. Sci. 2013, 1, 239-253. [CrossRef]

29. Santiago, G.T.-D.; Sharifi, R.; Yue, K.; Sani, E.S.; Kashaf, S.S.; Alvarez, M.M.; Leijten, J.; Khademhosseini, A.; Dana, R.; Annabi, N. Ocular adhesives: Design, chemistry, crosslinking mechanisms, and applications. Biomaterials 2019, 197, 345-367. [CrossRef]

30. Annabi, N.; Yue, K.; Tamayol, A.; Khademhosseini, A. Elastic sealants for surgical applications. Eur. J. Pharm. Biopharm. 2015, 95, 27-39. [CrossRef]

31. Bouten, P.J.; Zonjee, M.; Bender, J.; Yauw, S.T.; Van Goor, H.; Van Hest, J.C.M.; Hoogenboom, R. The chemistry of tissue adhesive materials. Prog. Polym. Sci. 2014, 39, 1375-1405. [CrossRef]

32. Stenzel, K.H.; Miyata, T.; Rubin, A.L. Collagen as a Biomaterial. Annu. Rev. Biophys. Bioeng. 1974, 3, $231-253$. [CrossRef] [PubMed]

33. Nikkhah, M.; Akbari, M.; Paul, A.; Memic, A.; Dolatshahi-Pirouz, A.; Khademhosseini, A. Gelatin-Based Biomaterials for Tissue Engineering And Stem Cell Bioengineering. In Biomaterials from Nature for Advanced Devices and Therapies; John Wiley \& Sons, Inc.: Hoboken, NJ, USA, 2016; pp. 37-62. [CrossRef]

34. Nichol, J.W.; Koshy, S.; Bae, H.; Hwang, C.M.; Yamanlar, S.; Khademhosseini, A. Cell-laden microengineered gelatin methacrylate hydrogels. Biomaterials 2010, 31, 5536-5544. [CrossRef] [PubMed]

35. Yin, J.; Yan, M.; Wang, Y.; Fu, J.; Suo, H. 3D Bioprinting of Low-Concentration Cell-Laden Gelatin Methacrylate (GelMA) Bioinks with a Two-Step Cross-linking Strategy. ACS Appl. Mater. Interfaces 2018, 10, 6849-6857. [CrossRef] [PubMed]

36. Draye, J.-P.; Delaey, B.; Van De Voorde, A.; Bulcke, A.V.D.; De Reu, B.; Schacht, E. In vitro and in vivo biocompatibility of dextran dialdehyde cross-linked gelatin hydrogel films. Biomaterials 1998, 19, 1677-1687. [CrossRef]

37. Nakayama, Y.; Matsuda, T. Photocurable Surgical Tissue Adhesive Glues Composed of Photoreactive Gelatin and Poly(Ethylene Glycol) Diacrylate. J. Biomed. Mater. Res. 1999, 48, 511-521. [CrossRef]

38. Kito, H.; Matsuda, T. Biocompatible Coatings for Luminal and Outer Surfaces of Small-Caliber Artificial Grafts. J. Biomed. Mater. Res. 1996, 30, 321-330. [CrossRef]

39. Okino, H.; Nakayama, Y.; Tanaka, M.; Matsuda, T. In situ hydrogelation of photocurable gelatin and drug release. J. Biomed. Mater. Res. 2002, 59, 233-245. [CrossRef]

40. Okino, H.; Maeyama, R.; Manabe, T.; Matsuda, T.; Tanaka, M. Trans-tissue, sustained release of gemcitabine from photocured gelatin gel inhibits the growth of heterotopic human pancreatic tumor in nude mice. Clin. Cancer Res. 2003, 9, 5786-5793.

41. Okino, H.; Manabe, T.; Tanaka, M.; Matsuda, T. Novel therapeutic strategy for prevention of malignant tumor recurrence after surgery: Local delivery and prolonged release of adenovirus immobilized in photocured, tissue-adhesive gelatinous matrix. J. Biomed. Mater. Res. 2003, 66, 643-651. [CrossRef] 
42. Elvin, C.M.; Vuocolo, T.; Brownlee, A.G.; Sando, L.; Huson, M.G.; Liyou, N.E.; Stockwell, P.R.; Lyons, R.E.; Kim, M.; Edwards, G.A.; et al. A highly elastic tissue sealant based on photopolymerised gelatin. Biomaterials 2010, 31, 8323-8331. [CrossRef] [PubMed]

43. Vuocolo, T.; Haddad, R.; Edwards, G.A.; Lyons, R.E.; Liyou, N.E.; Werkmeister, J.A.; Ramshaw, J.A.M.; Elvin, C.M. A Highly Elastic and Adhesive Gelatin Tissue Sealant for Gastrointestinal Surgery and Colon Anastomosis. J. Gastrointest. Surg. 2011, 16, 744-752. [CrossRef] [PubMed]

44. Liu, Y.; Ng, S.C.; Yu, J.; Tsai, W.-B. Modification and crosslinking of gelatin-based biomaterials as tissue adhesives. Colloids Surf. B Biointerfaces 2019, 174, 316-323. [CrossRef]

45. Assmann, A.; Vegh, A.; Ghasemi-Rad, M.; Bagherifard, S.; Cheng, G.; Sani, E.S.; Ruiz-Esparza, G.U.; Noshadi, I.; Lassaletta, A.D.; Gangadharan, S.P.; et al. A highly adhesive and naturally derived sealant. Biomaterials 2017, 140, 115-127. [CrossRef] [PubMed]

46. Sani, E.S.; Lara, R.P.; Aldawood, Z.; Bassir, S.H.; Nguyen, D.; Kantarci, A.; Intini, G.; Annabi, N. An Antimicrobial Dental Light Curable Bioadhesive Hydrogel for Treatment of Peri-Implant Diseases. Matter 2019, 1, 926-944. [CrossRef] [PubMed]

47. Herrick, S.; Blanc-Brude, O.; Gray, A.; Laurent, G. Fibrinogen. Int. J. Biochem. Cell Biol. 1999, 31, 741-746. [CrossRef]

48. Wolberg, A.S. Thrombin generation and fibrin clot structure. Blood Rev. 2007, 21, 131-142. [CrossRef] [PubMed]

49. Elvin, C.M.; Danon, S.J.; Brownlee, A.G.; White, J.; Hickey, M.; Liyou, N.E.; Edwards, G.A.; Ramshaw, J.A.M.; Werkmeister, J.A. Evaluation of photo-crosslinked fibrinogen as a rapid and strong tissue adhesive. J. Biomed. Mater. Res. Part A 2009, 9999, 687-695. [CrossRef] [PubMed]

50. Waite, J.H. Mussel adhesion-essential footwork. J. Exp. Biol. 2017, 220, 517-530. [CrossRef] [PubMed]

51. Stewart, R.J.; Wang, C.S.; Song, I.T.; Jones, J.P. The role of coacervation and phase transitions in the sandcastle worm adhesive system. Adv. Colloid Interface Sci. 2016, 239, 88-96. [CrossRef]

52. Yu, J.; Wei, W.; Menyo, M.S.; Masic, A.; Waite, J.H.; Israelachvili, J.N. Adhesion of Mussel Foot Protein-3 to $\mathrm{TiO}_{2}$ Surfaces: The Effect of pH. Biomacromolecules 2013, 14, 1072-1077. [CrossRef] [PubMed]

53. Wei, W.; Yu, J.; Broomell, C.; Israelachvili, J.N.; Waite, J.H. Hydrophobic Enhancement of Dopa-Mediated Adhesion in a Mussel Foot Protein. J. Am. Chem. Soc. 2012, 135, 377-383. [CrossRef] [PubMed]

54. Anderson, T.H.; Yu, J.; Estrada, A.; Hammer, M.U.; Waite, J.H.; Israelachvili, J.N. The Contribution of DOPA to Substrate-Peptide Adhesion and Internal Cohesion of Mussel-Inspired Synthetic Peptide Films. Adv. Funct. Mater. 2010, 20, 4196-4205. [CrossRef] [PubMed]

55. Kaur, S.; Narayanan, A.; Dalvi, S.; Liu, Q.; Joy, A.; Dhinojwala, A. Direct Observation of the Interplay of Catechol Binding and Polymer Hydrophobicity in a Mussel-Inspired Elastomeric Adhesive. ACS Cent. Sci. 2018, 4, 1420-1429. [CrossRef]

56. Jeon, E.Y.; Hwang, B.H.; Yang, Y.J.; Kim, B.J.; Choi, B.-H.; Jung, G.Y.; Cha, H.J. Rapidly light-activated surgical protein glue inspired by mussel adhesion and insect structural crosslinking. Biomaterials 2015, 67, 11-19. [CrossRef]

57. Wise, S.G.; Weiss, A.S. Tropoelastin. Int. J. Biochem. Cell Biol. 2009, 41, 494-497. [CrossRef]

58. Annabi, N.; Zhang, Y.-N.; Assmann, A.; Sani, E.S.; Cheng, G.Z.; Lassaletta, A.D.; Vegh, A.; Dehghani, B.; Ruiz-Esparza, G.U.; Wang, X.; et al. Engineering a highly elastic human protein-based sealant for surgical applications. Sci. Transl. Med. 2017, 9, eaai7466. [CrossRef]

59. Annabi, N.; Rana, D.; Sani, E.S.; Portillo-Lara, R.; Gifford, J.L.; Fares, M.M.; Mithieux, S.; Weiss, A.S. Engineering a sprayable and elastic hydrogel adhesive with antimicrobial properties for wound healing. Biomaterials 2017, 139, 229-243. [CrossRef]

60. Lee, K.Y.; Mooney, D.J. Alginate: Properties and biomedical applications. Prog. Polym. Sci. 2012, 37, $106-126$. [CrossRef]

61. Orive, G.; Ponce, S.; Bayat, A.; Gascón, A.R.; Igartua, M.; Pedraz, J.L. Biocompatibility of microcapsules for cell immobilization elaborated with different type of alginates. Biomaterials 2002, 23, 3825-3831. [CrossRef]

62. Chan, A.W.; Neufeld, R.J. Tuneable semi-synthetic network alginate for absorptive encapsulation and controlled release of protein therapeutics. Biomaterials 2010, 31, 9040-9047. [CrossRef] [PubMed]

63. Smeds, K.A.; Pfister-Serres, A.; Miki, D.; Dastgheib, K.; Inoue, M.; Hatchell, D.L.; Grinstaff, M.W. Photocrosslinkable polysaccharides for in situ hydrogel formation. J. Biomed. Mater. Res. 2001, 54, 115-121. [CrossRef] 
64. Charron, P.N.; Fenn, S.; Poniz, A.; Oldinski, R.A. Mechanical properties and failure analysis of visible light crosslinked alginate-based tissue sealants. J. Mech. Behav. Biomed. Mater. 2016, 59, 314-321. [CrossRef]

65. Croisier, F.; Jérôme, C. Chitosan-based biomaterials for tissue engineering. Eur. Polym. J. 2013, 49, 780-792. [CrossRef]

66. Li, J.; Celiz, A.D.; Yang, J.; Yang, Q.; Wamala, I.; Whyte, W.; Seo, B.R.; Vasilyev, N.V.; Vlassak, J.J.; Suo, Z.; et al. Tough adhesives for diverse wet surfaces. Science 2017, 357, 378-381. [CrossRef]

67. Ono, K.; Saito, Y.; Yura, H.; Ishikawa, K.; Kurita, A.; Akaike, T.; Ishihara, M. Photocrosslinkable Chitosan as a Biological Adhesive. J. Biomed. Mater. Res. 2000, 49, 289-295. [CrossRef]

68. Ishihara, M.; Ono, K.; Saito, Y.; Yura, H.; Hattori, H.; Matsui, T.; Kurita, A. Photocrosslinkable chitosan: An effective adhesive with surgical applications. Int. Congr. Ser. 2001, 1223, 251-257. [CrossRef]

69. Ishihara, M.; Nakanishi, K.; Ono, K.; Sato, M.; Kikuchi, M.; Saito, Y.; Yura, H.; Matsui, T.; Hattori, H.; Uenoyama, M.; et al. Photocrosslinkable chitosan as a dressing for wound occlusion and accelerator in healing process. Biomaterials 2002, 23, 833-840. [CrossRef]

70. Ishihara, M. Photocrosslinkable Chitosan Hydrogel as a Wound Dressing and a Biological Adhesive. Trends Glycosci. Glycotechnol. 2002, 14, 331-341. [CrossRef]

71. Zeng, Z.; Mo, X.-M.; He, C.; Morsi, Y.; El-Hamshary, H.; El-Newehy, M.H. An in situ forming tissue adhesive based on poly(ethylene glycol)-dimethacrylate and thiolated chitosan through the Michael reaction. J. Mater. Chem. B 2016, 4, 5585-5592. [CrossRef]

72. Gong, J.P.; Katsuyama, Y.; Kurokawa, T.; Osada, Y. Double-Network Hydrogels with Extremely High Mechanical Strength. Adv. Mater. 2003, 15, 1155-1158. [CrossRef]

73. Wang, L.; Zhang, X.; Yang, K.; Fu, Y.V.; Xu, T.; Li, S.; Zhang, D.; Wang, L.; Lee, C.-S. A Novel Double-Crosslinking-Double-Network Design for Injectable Hydrogels with Enhanced Tissue Adhesion and Antibacterial Capability for Wound Treatment. Adv. Funct. Mater. 2020, 30, 1904156. [CrossRef]

74. Amsden, B.G.; Sukarto, A.; Knight, D.K.; Shapka, S.N. Methacrylated Glycol Chitosan as a Photopolymerizable Biomaterial. Biomacromolecules 2007, 8, 3758-3766. [CrossRef] [PubMed]

75. Lu, M.; Liu, Y.; Huang, Y.-C.; Huang, C.-J.; Tsai, W.-B. Fabrication of photo-crosslinkable glycol chitosan hydrogel as a tissue adhesive. Carbohydr. Polym. 2018, 181, 668-674. [CrossRef]

76. Sugahara, K.; Mikami, T.; Uyama, T.; Mizuguchi, S.; Nomura, K.; Kitagawa, H. Recent advances in the structural biology of chondroitin sulfate and dermatan sulfate. Curr. Opin. Struct. Biol. 2003, 13, 612-620. [CrossRef]

77. Clegg, D.O.; Reda, M.J.; Harris, C.L.; Klein, M.A.; O’Dell, J.R.; Hooper, M.M.; Bradley, J.D.; Bingham, C.O.; Weisman, M.H.; Jackson, C.G.; et al. Glucosamine, Chondroitin Sulfate, and the Two in Combination for Painful Knee Osteoarthritis. N. Engl. J. Med. 2006, 354, 795-808. [CrossRef]

78. Wang, D.-A.; Varghese, S.; Sharma, B.; Strehin, I.; Fermanian, S.; Gorham, J.; Fairbrother, D.H.; Cascio, B.; Elisseeff, J.H. Multifunctional chondroitin sulphate for cartilage tissue-biomaterial integration. Nat. Mater. 2007, 6, 385-392. [CrossRef]

79. Heinze, T.; Liebert, T.; Heublein, B.; Hornig, S. Functional Polymers Based on Dextran. Adv. Polym. Sci. 2006, 205, 199-291. [CrossRef]

80. Hovgaard, L.; Brøndsted, H. Dextran hydrogels for colon-specific drug delivery. J. Control. Release 1995, 36, 159-166. [CrossRef]

81. Fleming, J.W.; Bloom, W.L. Further Observations on the Hemodynamic Effect of Plasma Volume Expansion by Dextran1. J. Clin. Investig. 1957, 36, 1233-1238. [CrossRef]

82. Bonnar, J.; Walsh, J. Prevention of Thrombosis after Pelvic Surgery by British Dextran 70. Lancet 1972, 299, 614-616. [CrossRef]

83. Li, H.; Niu, R.; Yang, J.; Nie, J.; Yang, D. Photocrosslinkable tissue adhesive based on dextran. Carbohydr. Polym. 2011, 86, 1578-1585. [CrossRef]

84. Wang, T.; Nie, J.; Yang, D. Dextran and gelatin based photocrosslinkable tissue adhesive. Carbohydr. Polym. 2012, 90, 1428-1436. [CrossRef]

85. Wang, T.; Mu, X.; Li, H.; Wu, W.; Nie, J.; Yang, D. The photocrosslinkable tissue adhesive based on copolymeric dextran/HEMA. Carbohydr. Polym. 2013, 92, 1423-1431. [CrossRef]

86. Li, C.; Wang, T.; Hu, L.; Wei, Y.; Liu, J.; Mu, X.; Nie, J.; Yang, D. Photocrosslinkable bioadhesive based on dextran and PEG derivatives. Mater. Sci. Eng. C 2014, 35, 300-306. [CrossRef] 
87. Necas, J.; Bartosikova, L.; Brauner, P.; Kolar, J. Hyaluronic acid (hyaluronan): A review. Vet. Med. 2008, 53, 397-411. [CrossRef]

88. Luo, Y.; Kirker, K.R.; Prestwich, G.D. Cross-linked hyaluronic acid hydrogel films: New biomaterials for drug delivery. J. Control. Release 2000, 69, 169-184. [CrossRef]

89. Miki, D.; Dastgheib, K.; Kim, T.; Pfister-Serres, A.; Smeds, K.A.; Inoue, M.; Hatchell, D.L.; Grinstaff, M.W. A Photopolymerized Sealant for Corneal Lacerations. Cornea 2002, 21, 393-399. [CrossRef] [PubMed]

90. Chandrasekharan, A.; Seong, K.-Y.; Yim, S.-G.; Kim, S.; Seo, S.; Yoon, J.; Yang, S.Y. In situ photocrosslinkable hyaluronic acid-based surgical glue with tunable mechanical properties and high adhesive strength. J. Polym. Sci. Part A Polym. Chem. 2018, 57, 522-530. [CrossRef]

91. Yang, Y.; Zhang, J.; Liu, Z.; Lin, Q.; Liu, X.; Bao, C.; Wang, Y.; Zhu, L. Tissue-Integratable and Biocompatible Photogelation by the Imine Crosslinking Reaction. Adv. Mater. 2016, 28, 2724-2730. [CrossRef]

92. Liu, X.; Yang, Y.; Niu, X.; Lin, Q.; Zhao, B.; Wang, Y.; Zhu, L. An in Situ Photocrosslinkable Platelet Rich Plasma-Complexed Hydrogel Glue with Growth Factor Controlled Release Ability to Promote Cartilage Defect Repair. Acta Biomater. 2017, 62, 179-187. [CrossRef] [PubMed]

93. Yang, Y.; Liu, X.; Li, Y.; Wang, Y.; Bao, C.; Chen, Y.; Lin, Q.; Zhu, L. A postoperative anti-adhesion barrier based on photoinduced imine-crosslinking hydrogel with tissue-adhesive ability. Acta Biomater. 2017, 62, 199-209. [CrossRef] [PubMed]

94. Hong, Y.; Zhou, F.; Hua, Y.; Zhang, X.; Ni, C.; Pan, D.; Zhang, Y.; Jiang, D.; Yang, L.; Lin, Q.; et al. A strongly adhesive hemostatic hydrogel for the repair of arterial and heart bleeds. Nat. Commun. 2019, 10, 2060. [CrossRef]

95. Miao, S.; Wang, P.; Su, Z.; Zhang, S. Vegetable-oil-based polymers as future polymeric biomaterials. Acta Biomater. 2014, 10, 1692-1704. [CrossRef]

96. Xu, Y.; Liu, Q.; Narayanan, A.; Jain, D.; Dhinojwala, A.; Joy, A. Mussel-Inspired Polyesters with Aliphatic Pendant Groups Demonstrate the Importance of Hydrophobicity in Underwater Adhesion. Adv. Mater. Interfaces 2017, 4, 1700506. [CrossRef]

97. Narayanan, A.; Kaur, S.; Peng, C.; Debnath, D.; Mishra, K.; Liu, Q.; Dhinojwala, A.; Joy, A. Viscosity Attunes the Adhesion of Bioinspired Low Modulus Polyester Adhesive Sealants to Wet Tissues. Biomacromolecules 2019, 20, 2577-2586. [CrossRef] 